\title{
Kepastian Hukum dan Budaya Korupsi di Indonesia
}

\author{
Boni Suparto Wuarlela ${ }^{1}$
}

\begin{abstract}
One of the biggest problems faced by the Unitary State of the Republic of Indonesia is the handling of the problem of corruption which seems to never end, both in terms of eradicating or implementing laws regarding corruption. In Indonesia, an independent institution specifically dealing with corruption issues has been established, namely the Corruption Eradication Commission (KPK) since 2002. However, the fact is that until 2020 it has not really been able to effectively address the problem of corruption in Indonesia with various arrests made by the Corruption Eradication Commission (KPK). proves that the problem of corruption that occurs in this country and the government in Indonesia needs serious attention from various parties who play an important role in dealing with the problem. This writing aims to determine the extent to which legal certainty applies in the process of eradicating corruption in Indonesia, the research method used is the normative research method. Based on the results of the research conducted, it can be concluded that the laws governing and law enforcement officials in overcoming the problem of corruption in Indonesia have not been fully effective in providing legal certainty to corrupt actors and the application of existing laws has not been able to fully guarantee the disappearance or no more corruption. will happen in the future, and there is a need for prevention that can give birth to new corruptors in the future by further increasing anticorruption learning programs and carrying out various socialization or prevention of acts of corruption from an early age which is felt to help overcome the problem of corruptors in this country.
\end{abstract}

Keywords : Legal Certainty, Corruption Eradication Commission, Corruption Perpetrators

\section{Latar Belakang Masalah}

Tindakan korupsi oleh para koruptor yang tenggelam dalam hasrat kekayaan dan kehidupan mewah di Indonesia sudah bukan lagi hal yang baru bagi bangsa ini, tindak pidana korupsi ini juga sudah menjadi hal yang sangat memprihatikan bagi Negara ini. Telah berbagai upaya yang dilakukan pemerintah mulai dari upaya pencegahan hingga penangkapan belum juga dapat memberikan efek jera agar dapat membuat para pelaku koruptor di Indonesia ini untuk berhenti dalam melakukan tindakan yang tidak terpuji tersebut. Bahkan dengan ancaman hukuman mati bagi para pelaku tindak pidana korupsi juga tidak dapat mencegah terjadinya Korupsi yang seolah-olah telah menjadi budaya dari bangsa ini khususnya para pelaku yang terjerat tindakan korupsi di Indonesia.

\footnotetext{
1 Institut IImu Sosial dan Bisnis Andi Sapada, Fakultas Hukum, Boni Suparto Wuarlela, boniwuarlela08@gmail.com
} 
Salah satu upaya yang dilakukan pemerintah dalam memberantas masalah Korupsi di Indonesia yaitu dengan dibentuknya lembaga Independen yaitu Komisi Pemberantasan Korupsi (KPK) sejak tahun 2002 yang hingga saat ini terus berupaya dalam menjalankan tugasnya yaitu mencegah, menghentikan ataupun menangkap para pelaku koruptor serta berbagai upaya pemerintah yang dikatakan terus berupaya memberdayagunakan serta memperkuat kewenangan hingga kemampuan KPK dengan cara Undang-undang tentang KPK terus mengalami revisi hingga yang terbaru saat ini telah disahkan dalam Undang-undang Nomor 19 Tahun 2019 yang juga masih menimbulkan kontroversi di masyarakat serta berbagai pro dan kontra khususnya dalam muatan atau isi Undang-undang tersebut.

Penyelenggaraan negara yang bersih tanpa tindakan korupsi sangat penting agar dapat menghindari praktek-praktek korupsi yang tidak saja melibatkan pejabat bersangkutan, tetapi juga oleh keluarga dan orang-orang terdekatnya yang apabila dibiarkan maka rakyat Indonesia akan sangat dirugikan. Menurut Nyoman Serikat Putra Jaya mengatakan bahwa tindak pidana korupsi tidak hanya dilakukan oleh penyelenggara negara, antar penyelenggara negara, melainkan juga penyelenggara negara dengan pihak lain seperti keluarga, kroni dan para pengusaha, sehingga merusak sendi-sendi kehidupan bermasyarakat, berbangsa, dan bernegara, serta membahayakan eksistensi negara. ${ }^{2}$

Perkembangan korupsi di Indonesia masih termasuk tinggi, sedangkan pemberantasannya masih begitu belum efektif. Romli Atmasasmita menyatakan bahwa korupsi di Indonesia sudah merupakan virus flu yang menyebar ke seluruh tubuh pemerintahan sejak tahun 1960-an langkah-langkah pemberantasannya pun masih tersendat-sendat sampai sekarang. Selanjutnya, dikatakan bahwa korupsi berkaitan pula dengan kekuasaan karena dengan kekuasaan itu penguasa dapat menyalahgunakan kekuasaannya untuk kepentingan pribadi, keluarga dan kroninya. ${ }^{3}$

Menurut salah satu Dosen IAIN Parepare, Dirga Achmad, M.H. beropini bahwa konsekuensi logis dari korupsi sebagai kejahatan luar biasa adalah proses hukum dan perlakuan terhadap koruptor harus dengan cara yang luar biasa pula. ${ }^{4}$ Namun menjadi masalah pula dalam hal pelaksanaan tindakan pencegahan, penangkapan hingga putusan dalam menjatuhkan hukuman bagi para pelaku tindakan korupsi sejauh ini dipandang belum dapat dikatakan seimbang dengan tindakan kejahatan luar biasa yang dilakukan oleh para koruptor seperti mulai dari fasilitas di dalam penjara serta beberapa kelonggaran lain ataupun pemotongan masa hukuman dengan berbagai pertimbangan.

Berdasarkan latar belakang tersebut maka penulis tertarik untuk membahas mengenai bagaimana kepastian hukum terhadap pelaku korupsi yang dianggap menjadi budaya di Indonesia, yang membuat tulisan ini menarik yaitu akan dibahas lebih lanjut bagaimana peran penuh Komisi Pemberantasan Korupsi bersama lembaga lainnya yang berwenang dalam

\footnotetext{
${ }^{2}$ Nyoman Serikat Putra Jaya. 2005. Tindak Pidana Korupsi, Kolusi dan Nepotisme di Indonesia. Semarang: Badan Penerbit Undip. hlm. 2

${ }^{3}$ Romli Atmasasmita. 2004. Sekitar Masalah Korupsi, Aspek Nasional dan Aspek Internasional. Bandung: Mandar Maju. hlm. 1

${ }^{4}$ https://www.iainpare.ac.id/opini-eks-koruptor-jadi-penyuluh-runtuhnya-semangat/ , diakses pada tanggal 28 Agustus 2021
} 
menangani masalah korupsi di Indonesia, kemudian bagaimana penerapan hukum serta kepastian hukum terhadap tindak pidana korupsi (tipikor) di Indonesia, serta bagaimana pandangan menurut para ahli yang menjadi penyebab terjadinya Tindakan Korupsi yang seakan-akan menjadi budaya di Negara ini.

\section{Metode Penelitian}

Metode penelitian ini menggunakan metode penelitian normatif, yakni Penelitian Hukum Normatif merupakan penelitian hukum yang dilakukan dengan cara meneliti bahan pustaka atau data sekunder. Penelitian hukum normatif disebut juga penelitian hukum doktrinal. Penelitian yang dilakukan bersifat deskriptif analitis yaitu menggambarkan, menganalisis, menyimpulkan masalah-masalah yang menjadi objek penelitian. ${ }^{5}$

\section{Pembahasan}

\section{A. Sejarah singkat, Fungsi dan Tugas Komisi Pemberantasan Korupsi (KPK)}

KPK dibentuk bukan untuk mengambil alih tugas pemberantasan korupsi dari lembaga hukum yang ada sebelumnya. KPK sebagai stimulus upaya pemberantasan korupsi di Indonesia. Cikal bakal KPK bermula pada masa reformasi tahun 1999, lahir Undang-undang Nomor 28 Tahun 1999 tentang Penyelenggara Negara yang Bersih dan Bebas dari KKN serta Undang-undang Nomor 31 Tahun 1999. Kemudian pada Tahun 2001 akhirnya lahir Undangundang Nomor 20 Tahun 2001 sebagai pengganti sekaligus pelengkap Undang-undang Nomor 31 Tahun 1999. Dengan Undang-undang Nomor 20 Tahun 2001, KPK pun terbentuk. Selanjutnya pada 27 Desember 2002 dikeluarkan Undang-undang Nomor 30 Tahun 2002 tentang Komisi Pemberantasan Tindak Pidana Korupsi. Dengan lahirnya KPK ini, maka pemberantasan korupsi di Indonesia mengalami babak baru. Tidak sampai disini, pada tahun 2019 dilakukan revisi Undang-undang Pemberantasan Korupsi menjadi Undang-undang Nomor 19 Tahun 2019 tentang perubahan kedua atas Undang-undang Nomor 30 Tahun $2002 .{ }^{6}$

Menurut Undang-undang Nomor 30 Tahun 2002 pasal 6, KPK memiliki tugas yaitu :

a) koordinasi dengan instansi yang berwenang melakukan pemberantasan tindak pidana korupsi

b) supervisi terhadap instansi yang berwenang melakukan pemberantasan tindak pidana korupsi

c) melakukan penyelidikan, penyidikan, dan penuntutan terhadap tindak pidana korupsi

d) melakukan tindakan-tindakan pencegahan tindak pidana korupsi dan

e) melakukan monitor terhadap penyelenggaraan pemerintahan negara.

\footnotetext{
${ }^{5}$ Syahruddin Nawi. 2017. Penelitian Hukum Normatif Versus Penelitian Hukum Empiris. PT. Umitoha Ukhuwah Grafika. hlm.9

${ }^{6} \mathrm{https}: / /$ voi.id/berita/33739/sejarah-tugas-dan-fungsi-yang-harus-dijalankan-kpk, diakses pada tanggal 22 Agustus 2021
} 
Dalam melaksanakan tugas koordinasi sebagaimana dimaksud dalam Pasal 6 huruf a, Komisi Pemberantasan Korupsi berwenang:

1. mengkoordinasikan penyelidikan, penyidikan, dan penuntutan tindak pidana korupsi

2. menetapkan sistem pelaporan dalam kegiatan pemberantasan tindak pidana korupsi

3. meminta informasi tentang kegiatan pemberantasan tindak pidana korupsi kepada instansi yang terkait

4. melaksanakan dengar pendapat atau pertemuan dengan instansi yang berwenang melakukan pemberantasan tindak pidana korupsi dan

5. meminta laporan instansi terkait mengenai pencegahan tindak pidana korupsi.

Lebih lanjut dalam menjalankan tugasnya, KPK berpedoman terhadap lima asas, antara lain:

- Asas Kepastian Hukum. Asas ini mengutamakan landasan peraturan perundangan, kepatutan, dan keadilan dalam setiap kewajiban penyelenggara negara.

-Asas Keterbukaan. Asas ini adalah yang membuka diri terhadap hak masyarakat untuk memperoleh informasi yang benar, jujur, dan tidak diskriminatif tentang penyelenggaraan negara, ini tetap memperhatikan perlindungan atas hak asasi pribadi, golongan dan rahasia negara.

-Asas Akuntabilitas. Asas ini yang menentukan bahwa setiap kegiatan dan hasil akhir dari kegiatan penyelenggaraan negara harus dapat dipertanggungjawabkan kepada masyarakat.

-Asas Kepentingan umum. Asas ini adalah mendahulukan kesejahteraan umum dengan cara aspiratif, akomodatif, dan selektif.

-Asas Proporsionalitas. Asas ini mengutamakan keseimbangan antara hak dan kewajiban. Tanggung jawab KPK kepada publik dan harus menyampaikan laporannya secara terbuka dan berkala kepada presiden, Dewan Perwakilan Rakyat (DPR) dan Badan Pemeriksaan Keuangan (BPK).

\section{B. Penegakan Hukum dalam Memberikan Kepastian Hukum terhadap Pelaku Tindak Pidana Korupsi}

Sistem penegakan hukum pada hakikatnya merupakan suatu sistem penegakan substansi hukum (di bidang hukum pidana meliputi hukum pidana materiel, hukum pidana formal, dan hukum pelaksana pidana). ${ }^{7}$ Sedangkan Jimly Asshiddiqie menyatakan, penegakan hukum adalah proses dilakukannya upaya tegaknya atau berfungsinya norma-norma hukum secara nyata sebagai prilaku dalam lalu lintas atau hubungan-hubungan hukum dalam kehidupan masyarakat dan bernegara. ${ }^{8}$

\footnotetext{
7 Heni Siswanto. (2013). Rekonstruksi Sistem Penegakan Hukum Pidana Menghadapi Kejahatan Perdagangan Orang. Semarang: Pustaka Magister, hlm. 77.

${ }^{8}$ Jimly Asshiddiqie. (2016). Penegakan Hukum, www.jimly.com, diakses pada tanggal 29 Agustus 2021
} 
Dalam hal penegakan terhadap kasus tindak pidana korupsi mulai dari proses pencegahan hingga penjatuhan hukuman terhadap pelaku korupsi yang menjadi lembaga penggerak yang seharusnya dapat memberikan kepastian hukum bagi masyarakat yang menjadi korban terhadap tindakan kejahatan luar biasa ini adalah lembaga-lembaga kehakiman baik dari pengadilan maupun kejaksaan bekerja sama dengan lembaga yang awalnya bersifat lembaga independen yang sekarang ini disebut telah menjadi bagian dari lembaga Negara karena telah mengalami perubahan terhadap Undang-undang Nomor 30 Tahun 2002 mengalami perubahan kedua yaitu Undang-undang Nomor 19 Tahun 2019 ini menjadi harapan besar bagi Negara ini agar dapat memberantas kegiatan ataupun mencegah terjadinya kejahatan luar biasa tindak pidana korupsi di Indonesia.

Penegakan hukum yang baik dalam implementasinya juga didukung kuat dari Undangundang yang menjadi pedoman agar memiliki wewenang pasti bagi para aparat penegak hukum dalam menjalankan tugasnya, namun dari apa yang terjadi hingga saat ini perubahan Undang-undang Nomor 30 Tahun 2002 menjadi Undang-undang Nomor 19 Tahun 2019 yang menimbulkan banyak perdebatan serta pro dan kontrak di masyarakat maupun para penggiat hukum Karena dianggap kurang mampu menopang ataupun melindungi aparat penegak hukum terhadap kewenangan yang akan dijalankan khususnya Komisi Pemberantasan Korupsi, hal ini berarti kepastian hukum terhadap tindakan pencegahan ataupun pemberantasan korupsi di Indonesia masih tergolong rendah atau belum memberikan kepastian hukum yang efektif bagi masyarakat maupun penegak hukum dalam menjalankan tugasnya.

Putusan hakim dalam perkara korupsi juga menjadi salah satu pemberi kepastian hukum terhadap tindakan korupsi. Di era reformasi dewasa ini seakan masyarakat memiliki hak yang penuh untuk menilai keadilan dalam setiap putusan hakim, sehingga tidak heran jika orang dengan mudah mengkritik dan menyalahkan putusan pengadilan tanpa memahami terlebih dahulu apa yang menjadi argumentasi dalam putusan tersebut. Paradigma yang berkembang saat ini bahwa dukungan masyarakat lebih banyak memihak pada permasalahan yang sedang popular dimasyarakat oleh pemberitaan media masa dan media elektronik.

Dari aspek instrument Kepastian hukum yang sering diartikan sebagai suatu penerapan secara Letterlijk atau menerapkan aturan (undang-undang) sesuai dengan teks undang-undang itu sendri, pendirian semacam itu banyak dipengaruhi oleh para penganutnya yaitu aliran legal positivism yang memandang hukum semata-mata adalah sekumpulan aturan-aturan, normanorma hukum dan asas-asas yang lebih lazim disebut undang-undang, padahal sebenarnya banyak hukum-hukum yang hidup dimasyarakat di luar undang-undang, seperti kebiasaankebiasaan, adat istiadat dan norma-norma agama. Kaidah dan norma-norma itu hidup dan diakui oleh para pendukungnya walaupun kaidah dan sanksi itu berbeda dengan kaidah dan sanksi dalam hukum positif.

Dalam perkara korupsi, pada umumnya orang berpandangan bahwa tidak ada putusan yang adil selain dengan hukuman pidana maksimal, sehingga setiap putusan yang dijatuhkan pengadilan selalu dianggap tidak adil dan mencederai rasa keadilan masyarakat, namun sebaliknya dalam perkara yang melibatkan orang kecil, seperti pada kasus pencurian kayu bakar atau pencurian sandal jepit, justru masyarakat selalu menganggap tidak adil jika mereka 
dijatuhi hukuman walaupun dengan jenis hukuman yang paling ringan sekalipun, lalu apakah konsep keadilan di era reformasi itu seperti demikian? Artinya setiap terdakwanya orang kecil, maka pengadilan tidak boleh menjatuhkan hukuman meskipun jelas-jelas telah terbukti bersalah dan setiap perkara korupsi tidak boleh dibebaskan atau diberikan hukuman yang ringan.

\section{Penyebab Terjadinya Tindak Pidana korupsi Menurut Para Ahli}

Penyebab Korupsi menurut para pakar yaitu Andi Hamzah, Baharuddin Lopa serta Djoko Prakoso yaitu ${ }^{9}$ :

a. Kurangnya gaji atau pendapatan pegawai negeri di banding dengan kebutuhan seharihari yang semakin lama semakin meningkat,

b. Ketidakberesan manajemen,

c. Modernisasi

d. Emosi mental,

e. Gabungan beberapa faktor.

Sedangkan menurut S. H. Alatas korupsi terjadi disebabkan oleh factor-faktor berikut : ${ }^{10}$

a. Ketiadaan atau kelemahan kepemimpinan dalam posisi-posisi kunci yang mampu memberikan ilham dan mempengaruhi tingkah laku yang menjinakkan korupsi,

b. Kelemahan pengajaran-pengajaran agama dan etika,

c. Kolonialisme,

d. Kurangnya pendidikan,

e. Kemiskinan,

f. Tiadanya hukuman yang keras,

g. Kelangkaan lingkungan yang subur untuk perilaku anti korupsi,

h. Struktur pemerintahan,

i. Perubahan radikal, dan

j. Keadaan masyarakat.

Abdullah Hehamahua melihat ada tiga factor penyebab korupsi di Indonesia, yaitu:

Pertama, konsumsi tinggi dan rendahnya gaji. Sudah jadi rahasia umum bahwa masyarakat Indonesia adalah masyarakat yang sangat konsumtif, tidak sedikit yang sampai shopping ke luar negeri sementara gaji pegawai rata-rata di Indonesia hanya cukup dua minggu. Nasib dua minggu berikutnya tergantung dari kreatifitasnya masing-masing yang salah satu kreatifitas tersebut dengan melakukan KKN (Korupsi, Kolusi dan Nepotisme).

Kedua, Pengawasan pembangunan yang tidak efektif. Karena pengawasan pembangunan yang lemah maka membuka peluang yang seluas-luasnya untuk melakukan penyalahgunaan semisal mark up dan lain sebagainya dan Ketiga, sikap serakah pejabat. ${ }^{11}$

\footnotetext{
${ }^{9}$ Gabungan beberapa pendapat para pakar yakni Andi Hamzah dalam Korupsi di Indonesia Masalah dan pemecahannya, hlm. 17 dan 22., Baharuddin Lopa, Permasalahan Pembinaan dan Penegakan Hukum di Indonesia, dan Djoko Prakoso, Peranan Pengawasan dalam Penangkalan Tindak Pidana Korupsi, hlm. 83.

${ }^{10}$ Syed Hussein Alatas, op.cit, hlm. 46-47
} 
Dari beberapa pandangan serta pendapat dari para ahli di atas dapat dilihat bahwa faktor terbesar yang dapat menyebabkan terjadinya tindak pidana korupsi yaitu masih kurangnya kesadaraan diri dan pola pikir dari setiap orang yang terikat oleh hukum serta keadaan sosial dari masing-masing masyarakat yang kurang atau dianggap tidak dapat memenuhi setiap kebutuhan hidupnya masing-masing.

\section{Penutup}

Melalui sejarah serta kinerja dari Komisi Pemberantasan Korupsi (KPK) sejauh ini yang merupakan salah satu upaya pemerintah dalam membersihkan tindakan korupsi yang dipandang seakan-akan telah menjadi budaya pada bangsa Indonesia ini. Kerja keras lembaga KPK ini juga ditunjang dengan dukungan dari para lembaga penegak hukum lainnya seperti Pengadilan dan Kejaksaan serta kewenangan yang diberikan Undang-undang dalam menjalankan tugasnya. Hal ini tidak terlepas dari pandangan masyarakat yang merupakan korban utama dalam perilaku para koruptor yang terjadi hingga saat ini dianggap belum dapat sepenuhnya diatasi oleh pemerintah mulai dari tindakan pencegahan hingga putusan yang dijatuhkan. Dalam perkara korupsi, pada umumnya orang berpandangan bahwa tidak ada putusan yang adil selain dengan hukuman pidana maksimal, sehingga setiap putusan yang dijatuhkan pengadilan selalu dianggap tidak adil dan mencederai rasa keadilan masyarakat, begitupula dengan KPK yang mempunyai tugas pokok yang tertuang dalam Undang-undang Nomor 19 Tahun 2019 tentang Perubahan kedua atas Undang-undang Nomor 30 Tahun 2002 Tentang Komisi Pemberantasan Tindak Pidana Korupsi yang juga dinilai belum dapat memberikan kepastian hukum terhadap kewenangan yang akan diimplementasikan dan dijalankan oleh KPK. Faktor terbesar yang dapat menyebabkan terjadinya tindak pidana korupsi yaitu masih kurangnya kesadaraan diri dan pola pikir dari setiap orang yang terikat oleh hukum serta keadaan sosial dari masing-masing masyarakat yang kurang atau dianggap tidak dapat memenuhi setiap kebutuhan hidupnya masing-masing.

\section{Referensi}

Abdullah hehamahua, Membangun Gerakan Antikorupsi Dalam Perspektif Pengadilan, LP3 UMY, Yogyakarta, 2004, hlm. 15-19.

Gabungan beberapa pendapat para pakar yakni Andi Hamzah dalam Korupsi di Indonesia Masalah dan pemecahannya, hlm. 17 dan 22., Baharuddin Lopa, Permasalahan Pembinaan dan Penegakan Hukum di Indonesia, dan Djoko Prakoso, Peranan Pengawasan dalam Penangkalan Tindak Pidana Korupsi, hlm. 83.

Heni Siswanto. (2013). Rekonstruksi Sistem Penegakan Hukum Pidana Menghadapi Kejahatan Perdagangan Orang. Semarang: Pustaka Magister, hlm. 77.

${ }^{11}$ Abdullah hehamahua, Membangun Gerakan Antikorupsi Dalam Perspektif Pengadilan, LP3 UMY, Yogyakarta, 2004, hlm. 15-19. 
Nyoman Serikat Putra Jaya. 2005. Tindak Pidana Korupsi, Kolusi dan Nepotisme di Indonesia. Semarang: Badan Penerbit Undip. hIm. 2

Romli Atmasasmita. 2004. Sekitar Masalah Korupsi, Aspek Nasional dan Aspek Internasional. Bandung: Mandar Maju. hlm. 1

Syahruddin Nawi. 2017. Penelitian Hukum Normatif Versus Penelitian Hukum Empiris. PT. Umitoha Ukhuwah Grafika. hlm.9

Syed Hussein Alatas, op.cit, hlm. 46-47

\section{Internet :}

https://voi.id/berita/33739/sejarah-tugas-dan-fungsi-yang-harus-dijalankan-kpk, diakses pada tanggal 22 Agustus 2021

https://www.iainpare.ac.id/opini-eks-koruptor-jadi-penyuluh-runtuhnya-semangat/ ,diakses pada tanggal 28 Agustus 2021

Jimly Asshiddiqie. (2016). Penegakan Hukum, www.jimly.com, diakses pada tanggal 29 Agustus 2021

\section{Penulisan Undang-undang}

Undang-undang Dasar tahun 1945

Undang-undang Nomor 28 Tahun 1999

Undang-undang Nomor 31 Tahun 1999.

Undang-undang Nomor 20 Tahun 2001

Undang-undang Nomor 30 Tahun 2002

Undang-undang Nomor 19 Tahun 2019 